\title{
Era Baru: Persepsi Mendasar Wajib Pajak terhadap Tingkat Kepatuhan Pajak
}

\author{
Gandy Wahyu Maulana Zulma, Lutfi, Muhammad Gowon \\ Universitas Jambi, Indonesia \\ Correspondence email: maulanagandi25@gmail.com
}

\begin{abstract}
The aim of this study to investigate empirical evidence about the fundamental perceptions of taxpayers related to tax administration and tax policy on tax compliance. This research is a quantitative study using a questionnaire in 5 Likert scales. The sample of observations in this study amounted to 110 respondents with different backgrounds. The results of this study indicate that there is a proven positive effect between the fundamental perceptions of taxpayers from administrative factors and tax policies on tax compliance. The higher the taxpayer's perception of the tax administration and government tax policy, the higher the taxpayer's motivation to comply with it.
\end{abstract}

Keywords : Tax Administration; Tax Compliance; Tax Policy; and Perceptions of Taxpayers

\section{PENDAHULUAN}

Rendahnya tingkat kepatuhan pajak di Indonesia dapat terlihat dari stagnannya penerimaan pajak yang berbanding terbalik dengan pengeluaran negara yang terus meningkat. Penerimaan pajak hingga 2018 baru mencapai $\mathrm{Rp} 1.016,52$ triliun dari target seharusnya mencapai $\mathrm{Rp} 1.424$ triliun dengan persentase pencapaian 71,39\% dari target APBN 2018. Selain itu, apabila mengacu pada target pajak tahun 2019 yang lebih tinggi yaitu sebesar Rp 1.577,6 triliun dengan tax ratio 12,11\% membuat posisi pemerintah semakin sulit untuk meningkatkan penerimaan pajak di Indonesia (Inside Tax, 2019). Hal ini mengindikasikan bahwa pemerintah masih mengalami masalah mengenai rendahnya tingkat kepatuhan pajak di Indonesia. Banyak literatur sebelunya yang berusaha untuk menjelaskan mengenai fenomena kepatuhan pajak di setiap negara yang dijelaskan baik secara aspek ekonomi maupun non ekonomi, namun secara umum hasilnya dapat dikatakan hanya bersifat dugaan dan prediksi semata. Beberapa penelitian dengan paradigma neo klasik membahas mengenai sebuah pertanyaan besar yang perlu dijawab untuk mempelajari perilaku wajib pajak tentang "perlukah orang membayar pajak disaat mereka mempunyai kesempatan untuk menghindarinya?", sampai sekarang pertanyaan ini masih sulit dijelaskan dan memunculkan banyak alternatif penjelasan sehingga semakin menarik untuk terus dieksplorasi mengenai dasar perilaku wajib pajak untuk mematuhi kewajiban perpajakannya (Ritsatos, 2014).

Penelitian sebelumnya yang dilakukan di Negara berkembang seperti Afrika, Ghana dan Uganda menunjukkan hasil bahwa kepatuhan pajak sangat dipengaruhi oleh karakteristik, maupun moral masyarakat untuk menghindari pajak. Selain itu, faktor administrasi pajak di Negara berkembang yang dinilai kurang baik dapat merubah persepsi masyarakat untuk tidak membayar pajak (James dan Alley, 2004). Menarik untuk melihat bagaimana faktor-faktor tersebut seperti yang dialami oleh 3 negara berkembang di atas jika diterapkan di Indonesia yang notabanenya juga merupakan negara berkembang. Penelitian ini berusaha menggambarkan bagaimana persepsi mendasar wajib pajak di Indonesia yang dilihat berdasarkan pandangannya mengenai administrasi pajak serta kebijakan perpajakan yang berlaku dapat mempengaruhi tingkat kepatuhan dalam memenuhi hak dan kewajiban perpajakannya. Dalam tujuan mewujudkan keadilan social, kebijakan perpajakan dapat dijadikan solusi alternatif, mekanisme distribusi anggaran jadi andalan di beberapa negara berkembang, baik melalui subsidi, bantuan tunai, anggaran pendidikan dan lain-lain, namun dalam jangka panjang cenderung dampak distributif yang dihasilkan relatif menurun (Coady, de Mooij, dan Shang; 2015).

Dalam kaitannya dengan penerapan kebijakan di dunia perpajakan yang telah ditempuh oleh pemerintah seperti pemberian insentif terhadap tarif pajak, fasilitas bagi kegiatan pendidikan dan keagamaan, hingga pengecualian objek PPN atas barang kebutuhan primer seharusnya dapat secara optimal meningkatkan kepatuhan pajak karena manfaat yang telah dirasakan oleh masyarakat. Selain itu, mengenai administrasi perpajakan sudah menjadi agenda klasik yang selalu muncul dalam regulasi perpajakan. Meskipun, dalam kenyataannya banyak negara-negara lain yang mengalami kegagalan dalam menerapkan 
reformasi perpajakan karena melaksanakan perbaikan administrasi pajak tetapi tidak ditunjang dengan perbaikan tatakelola dan kualitas sumberdaya manusia nya (Bird, R.M., 2015). Berdasarkan topik menarik dan permasalahan kepatuhan pajak yang terjadi di Indonesia, penelitian ini bermaksud mengisi gap penelitian dengan cara berkontribusi pada eksplorasi jawaban atas pertanyaan mengenai persepsi mendasar wajib pajak yang mempengaruhi tingkat kepatuhan pajak dengan menetapkan hubungan antara alasan Wajib pajak untuk tidak membayar pajak dan faktor-faktor apa saja yang perlu diperhatikan agar dapat meningkatkan kesadaran masyarakat untuk taat membayar pajak.

\section{Tinjauan Literatur dan Pengembangan Hipotesis}

Dasar teori kepatuhan pajak berakar pada James and Alley's (2004) yang melakukan presentasi tipologi pendekatan kepatuhan pajak berdasarkan pendekatan ekonomi dan pendekatan perilaku. Pendekatan ekonomi melihat persepsi wajib pajak ditentukan oleh rasionalitas yang ditunjukkan oleh trade-off antara menimbang manfaat yang diharapkan dari menghindari pajak dengan risiko deteksi dan sanksi hukuman apabila melanggar peraturan pajak. Dalam pendekatan ini, wajib pajak diasumsikan akan memaksimalkan keuntungan dan kekayaan pribadi sehingga wajib pajak dianggap cenderung mempertimbangkan keuntungan dari penghindaran pajak dibandingkan risiko sanksi yang akan diterima jika terdeteksi melakukan pelanggaran.

Berbeda dengan teori di atas, Sanya dan Mulondo (2015) menunjukkan bahwa dalam kenyataannya tidak semua wajib pajak menghindari pajak, masih banyak individu maupun badan yang memiliki kesadaran yang baik sehingga kepatuhan pajaknya juga baik, sehingga pendekatan ekonomi rasional tidak selalu dapat dijadikan acuan dalam menggambarkan tingkat kepatuhan wajib pajak. Berdasarkan kedua teori di atas, penelitian ini berusaha untuk menghubungkan teori-teori tersebut dengan mengeksplorasi persepsi wajib pajak orang pribadi yang dianggap rasional dan memiliki ego untuk memaksimalkan keuntungan, namun wajib pajak juga mempunyai sikap, kepercayaan, norma, dan peran yang berbeda dengan otoritas pajak yang perlu dipahami agar dapat mewujudkan system perpajakan yang lebih baik.

\section{Administrasi Pajak dan Kepatuhan Pajak}

Pada literatur sebelumnya dan teori kepatuhan pajak menunjukkan bahwa tingkat kepatuhan pajak biasanya sangat berhubungan dengan bagaimana bentuk administrasi pajak di suatu negara (Bagchi et.al, 1995). Dalam mewujudkan administrasi pajak yang efektif tentunya perlu untuk membangun lingkungan dimana masyarakat didorong untuk mematuhi undang-undang perpajakan secara sukarela yang sejalan dengan teori kepatuhan di atas yang menunjukkan bahwa terdapat wajib pajak yang memiliki kesadaran yang baik atau secara sukarela taat membayar pajak. Lingkungan ini dapat terwujud apabila masyarakat mempunyai alasan yang kuat untuk tetap patuh terhadap aturan pajak seperti yang telah diidentifikasi oleh Frey dan Torgler (2007) misalnya seperti faktor suara wajib pajak, akuntabilitas pajak dan efektivitas pemerintah.

Dalam meningkatkan kesadaran pajak, pemerintah Indonesia melakukan berbagai perbaikan terhadap sistem pelayanan perpajakan seperti memperluas cakupan tempat pemberian pelayanan pajak, perluasan cakupan $e$-filling dan memberikan kemudahan restitusi pajak. Dibidang pengawasan, pemerintah berusaha mengimplementasikan akses informasi keuangan secara online, dan membenahi basis data perpajakan di Indonesia serta menerapkan pengawasan wajib pajak berbasis risiko/compliance risk management (Inside Tax, 2019). Perbaikan administrasi perpajakan merupakan agenda pemerintah dalam reformasi pajak untuk menunjang kesadaran wajib pajak dalam memenuhi hak dan kewajiban perpajakannya.

Berdasarkan literatur sebelumnya dan upaya yang telah dilakukan oleh pemerintah dalam meningkatkan kepatuhan pajak. Penelitian ini bermaksud untuk menguji secara empiris apakah persepsi mendasar wajib pajak dalam hal administrasi perpajakan yang digambarkan melalui transparansi sistem perpajakan, akuntabilitas dan kepercayaan wajib pajak terhadap pemerintah, serta efektivitas pemerintah dalam mengelola penerimaan pajak dengan baik yang dapat meningkatkan kepatuhan pajak. Seperti yang ditemukan dalam penelitian sebelumnya seperti Antonides dan Robben (1995) dan Webley (2004). Berdasarkan literature sebelumnya, maka penelitian ini menduga bahwa persepsi wajib pajak terhadap administrasi perpajakan dapat meningkatkan kepatuhan pajak. 


\section{(compliance tax) \\ Kebijakan Pajak dan Kepatuhan Pajak}

H1: Administrasi Perpajakan (tax administration) berpengaruh positif terhadap kepatuhan pajak

Simons dan Cheng (1996) mengidentifikasi berbagai faktor yang dapat mempengaruhi kepatuhan pajak seperti persepsi wajib pajak terkait ketidakadilan dalam sistem perpajakan, tingkat tarif pajak yang berlaku, bagaimana persepsi wajib pajak mengenai nilai dan kebijakan distribusi pengeluaran pajak pemerintah, serta persepsi terkait penghindaran pajak dengan memanfaatkan kelemahan aturan pajak yang terjadi di sekitar lingkungan mereka. Hal ini menunjukkan bahwa wajib pajak dapapt merespon faktor-faktor tersebut sebagai dasar mereka untuk menentukan sikap dalam mematuhi aturan perpajakan. Apabila mereka menilai bahwa kebijakan perpajakan sudah berjalan dengan baik, maka wajib pajak akan semakin mematuhi peraturan perpajakan yang berlaku.

Dalam tujuan penegakan hukum, pemerintah Indonesia telah berupaya melaksanakan penegakan hukum (law enforcement) secara berkeadilan. Selain itu, pemerintah telah berusaha dalam meningkatkan mutu pemeriksaan melalui perbaikan tatakelola pemeriksaan hingga saat ini. Untuk kebijakan secara khusus mengenai kepabeanan dan cukai, pemerintah berusaha menurunkan biaya logistic, menambah perluasan fasilitas kemudahan impor tujuan ekspor (KITE) untuk industri kecil dan menengah, serta memberantas penyelendupan dan penertiban barang kena cukai illegal (Inside tax, 2019). Kebijakan-kebijakan tersebut diambil oleh pemerintah dalam rangka untuk menertibkan serta meningkatkan kepatuhan pajak di Indonesia. Berdasarkan tinjauan literatur dan kebijakan yang telah dilaksanakan oleh pemerintah, maka penelitian ini menduga bahwa persepsi wajib pajak terhadap kebijakan pemerintah dalam menangani masalah mengenai tingkat tarif pajak yang ditetapkan serta pendistribusian pajak dapat meningkatkan kepatuhan masyarakat dalam memenuhi hak dan kewajiban perpajakannya.

H2: Kebijakan Pajak (tax policy) berpengaruh positif terhadap kepatuhan pajak (compliance tax)

\section{METODE PENELITIAN}

Populasi dalam penelitian ini merupakan wajib pajak dalam negeri baik yang bekerja sebagai pegawai tetap maupun tidak tetap, pemilik usaha, pegawai negeri sipil dan lain-lain. Sampel dikumpulkan berdasarkan kuesioner yang disebar secara langsung melalui asistensi penelitian serta sebagian kuesioner juga disebarkan melalui elektronik. Berdasarkan 300 kuesioner fisik yang disebarkan secara langsung kepada responden, diterima kembali kuesioner yang layak sebanyak 95 responden dengan tingkat persentase pengembalian $31,6 \%$. Sedangkan sisanya sebanyak 15 responden diperoleh dari kuesioner elektronik, sehingga total keseluruhan sebanyak 110 sampel observasi yang dapat dijadikan data dalam penelitian ini. Hal ini menunjukkan bahwa masih rendahnya kepedulian responden dalam mengisi kuesioner penelitian di Indonesia, khususnya untuk kuesioner yang dikirimkan melalui email.

Untuk menguji hipotesis 1 dan 2 dalam penelitian ini digunakan aplikasi pengolahan data yaitu IBM SPSS Statistic 23 dengan model regresi berganda yang telah memenuhi serangkaian uji asumsi klasik seperti uji validitas dan reliabilitas baik terhadap butir perntaan kuesioner untuk variabel independen maupun dependen. Kemudian, uji normalitas data, uji multikolinearitas, uji heteroskedastisitas dan uji autokorelasi yang mengacu pada Imam Ghozali (2011). Adapun model persamaan regresi berganda, sebagai berikut:

\section{Tax_Compliance $=\beta \_0+\beta \_1$ Tax_Administration $+\beta \_2$ Tax_Policy $+\epsilon \_$it}

\section{Operasionalisasi Variabel}

Variabel dependen dalam penelitian ini merupakan variabel kepatuhan pajak (Tax_Compliance) yang diukur berdasarkan aspek pendistribusian pajak (3 butir pernyataan) dan aspek persepsi ketidaksetaraan ( 5 butir pernyataan) yang diukur dengan menggunakan 5 skala likert dimulai dari jawaban sangat tidak setuju (STS) hingga Sangat Setuju (SS). Selain itu, penelitian ini mempunyai 2 variabel independen yaitu variabel Tax_Administration dan Tax_Policy. Adapun variabel Tax_Administration diukur berdasarkan aspek transparansi sistem perpajakan (4 butir pernyataan), akuntabilitas dan pendapat wajib pajak (4 butir pernyataan), serta efektivitas pemerintahan (3 butir pernyataan). Sedangkan variabel Tax_Policy diukur berdasarkan persepsi terkait tarif pajak ( 3 butir pernyataan), dan persepsi terkait penghindaran pajak (3 butir 
pernyataan). Keseluruhan pernyataan dalam kuesioner disusun dengan mempertimbangkan kebutuhan teori dan literatur serta fenomena yang terjadi mengenai persepsi mendasar wajib pajak terhadap tingkat kepatuhan pajak di Indonesia.

\section{HASIL DAN PEMBAHASAN}

Berdasarkan Tabel 1 dapat dilihat karakteristik dari responden dalam penelitian ini yang dikelompokkan berdasarkan jenis kelamin, umur, pekerjaan, kepemilikan NPWP, pengalaman melapor SPT serta aplikasi pajak yang digunakan. Dapat dilihat bahwa responden di dominasi oleh laki-laki yaitu sebanyak $70 \%$ dan sisanya perempuan yang secara umum berada diusia lebih dari 30 tahun (60\%) dengan pekerjaan sebagai karyawan tetap sebanyak $60,9 \%$, pegawai tidak tetap sebanyak 4,5\%, pemilik usaha sebanyak $16,4 \%$ dan sisanya tidak memberikan keterangan mengenai pekerjaannya. Selain itu, dari keseluruhan responden yang ditemui ternyata masih terdapat sekitar 35,5\% belum mempunyai NPWP dan 37,3\% tidak melaporkan SPT. Sedangkan aplikasi pajak yang favorit untuk digunakan yaitu aplikasi e-filing $(61,8 \%)$ dan e-spt $(19,1 \%)$. Berdasarkan karakteristik dari responden yang telah dijabarkan di atas, dapat disimpulkan bahwa karakteristiknya cukup bervariasi sehingga diharapkan dapat menunjang variabel dalam model penelitian ini.

Tabel 1

Deskriptif Responden

\begin{tabular}{|c|c|c|c|}
\hline No & Keterangan & Frekuensi & Persentase \\
\hline \multirow[t]{4}{*}{1} & Jenis Kelamin & & \\
\hline & a. Laki-laki & 77 & $70.0 \%$ \\
\hline & b. Perempuan & 33 & $30.0 \%$ \\
\hline & Jumlah & 110 & $100.0 \%$ \\
\hline \multirow[t]{5}{*}{2} & Umur & & \\
\hline & a. $<20$ Tahun & 6 & $5.5 \%$ \\
\hline & b. 20 s.d 30 Tahun & 38 & $34.5 \%$ \\
\hline & c. $>30$ Tahun & 66 & $60.0 \%$ \\
\hline & Jumlah & 110 & $100.0 \%$ \\
\hline \multirow[t]{6}{*}{3} & Pekerjaan & & \\
\hline & a. Karyawan Tetap & 67 & $60.9 \%$ \\
\hline & b. Tidak Tetap & 5 & $4.5 \%$ \\
\hline & c. Pemilik Usaha & 18 & $16.4 \%$ \\
\hline & d. N/A & 20 & $18.2 \%$ \\
\hline & Jumlah & 110 & $100.00 \%$ \\
\hline \multirow[t]{4}{*}{4} & Memiliki NPWP & & \\
\hline & a. $\mathrm{Ya}$ & 71 & $64.5 \%$ \\
\hline & b. Tidak & 39 & $35.5 \%$ \\
\hline & Jumlah & 110 & $100.00 \%$ \\
\hline \multirow[t]{4}{*}{5} & Lapor SPT & & \\
\hline & a. Ya & 69 & $62.7 \%$ \\
\hline & b. Tidak & 41 & $37.3 \%$ \\
\hline & Jumlah & 110 & $100.00 \%$ \\
\hline \multirow[t]{5}{*}{6} & Aplikasi Pajak & & \\
\hline & a. e-filling & 68 & $61,8 \%$ \\
\hline & b. e-spt & 21 & $19,1 \%$ \\
\hline & c. e-faktur & 8 & $7,3 \%$ \\
\hline & d. e-billing & 13 & $11,8 \%$ \\
\hline
\end{tabular}

Sumber: data olahan

\section{Pengujian Validitas dan Reliabilitas}

Tabel 2 menunjukkan ringkasan dari hasil pengujian validitas dan reliabilitas dari butir soal yang digunakan dalam penelitian ini. Menurut Wiratna Sujarweni (2014), suatu butir soal yang digunakan dalam kuesioner dapat dikatakan valid apabila nilai $r_{\text {hitung }}$ lebih besar dari nilai $r_{\text {tabel }}$. Dalam penelitian ini, awalnya terdapat 25 butir pernyataan yang digunakan dalam kuesioner penelitian. Namun, sebagian butir pernyataan harus dikeluarkan karena tidak memenuhi kriteria validitas yang ditelah ditetapkan. Setelah butir 
pernyataan tersebut dikeluarkan kemudian dilakukan ulang pengujian validitas, sehingga menghasilkan sebanyak 21 butir pernyataan yang memenuhi kriteria validitas.

Dalam pengujian reliabilitas, penelitian ini menggunakan metode Guttman Split-Half Coeficient. Suatu instrument penelitian dapat dikatakan "reliable" apabila nilai korelasi Guttman Split-Half Coeficient lebih dari 0,80 (Jonathan Sarwono, 2006). Berdasarkan tabel 2, dapat dilihat bahwa pada variabel independen yang diukur terdapat nilai Guttman Split-Half Coeficient sebesar 0,85 yang lebih besar dari 0,80 sehingga dapat dikatakan bahwa instrument yang digunakan untuk mengukur kedua variabel independen dalam penelitian ini telah memenuhi kriteria reliabilitas yang baik. Selain itu, pada variabel dependen yang diamati terdapat nilai Guttman Split-Half Coeficient sebesar 0,82 yang lebih besar dari 0,80. Berdasarkan nilai di atas, dapat disimpulkan bahwa instrument yang digunakan untuk variabel dependen maupun independen sudah memenuhi kriteria reliabilitas maupun validitas yang disyaratkan.

Tabel 2

Uji Validitas dan Reliabilitas

\begin{tabular}{|c|c|c|c|}
\hline \multicolumn{4}{|c|}{ Hasil Uji Validitas dan Reliabilitas Variabel } \\
\hline \multirow{2}{*}{$\begin{array}{l}\text { No Butir Soal } \\
\text { Variahol Indenenden }\end{array}$} & $\boldsymbol{r}_{\text {hitung }}$ & $r_{\text {tabel }} 5 \%(n=110)$ & \multirow[t]{2}{*}{ Kriteria } \\
\hline & \multicolumn{2}{|c|}{ Variabel Independen } & \\
\hline \multicolumn{4}{|l|}{ Tax_Administration $\left(x_{1}\right)$} \\
\hline $\mathrm{x} 1.1$ & 0.51 & 0.19 & Valid \\
\hline $\mathrm{x} 1.2$ & 0.48 & 0.19 & Valid \\
\hline $\mathrm{x} 1.4$ & 0.70 & 0.19 & Valid \\
\hline $\mathrm{x} 1.5$ & 0.69 & 0.19 & Valid \\
\hline $\mathrm{x} 1.6$ & 0.64 & 0.19 & Valid \\
\hline $\mathrm{x} 1.7$ & 0.51 & 0.19 & Valid \\
\hline $\mathrm{x} 1.8$ & 0.64 & 0.19 & Valid \\
\hline $\mathrm{x} 1.9$ & 0.67 & 0.19 & Valid \\
\hline $\mathrm{x} 1.10$ & 0.65 & 0.19 & Valid \\
\hline $\mathrm{x} 1.11$ & 0.75 & 0.19 & Valid \\
\hline \multicolumn{4}{|l|}{ Tax_Policy $\left(x_{2}\right)$} \\
\hline $\mathrm{x} 2.1$ & 0.77 & 0.19 & Valid \\
\hline $\mathrm{x} 2.2$ & 0.74 & 0.19 & Valid \\
\hline Guttman-Split Half Coeficient & 0.85 & $\mathbf{0 . 8 0}$ & Reliabel \\
\hline \multicolumn{4}{|l|}{ Variabel Dependen } \\
\hline \multicolumn{4}{|l|}{ Tax Compliance (y) } \\
\hline $\mathrm{y} 1$ & 0.48 & 0.19 & Valid \\
\hline y3 & 0.53 & 0.19 & Valid \\
\hline y4 & 0.45 & 0.19 & Valid \\
\hline y5 & 0.46 & 0.19 & Valid \\
\hline y6 & 0.52 & 0.19 & Valid \\
\hline y7 & 0.63 & 0.19 & Valid \\
\hline y8 & 0.66 & 0.19 & Valid \\
\hline Guttman-Split Half Coeficient & 0.82 & $\mathbf{0 . 8 0}$ & Reliabel \\
\hline
\end{tabular}

Sumber: data olahan

\section{Pengujian Hipotesis}




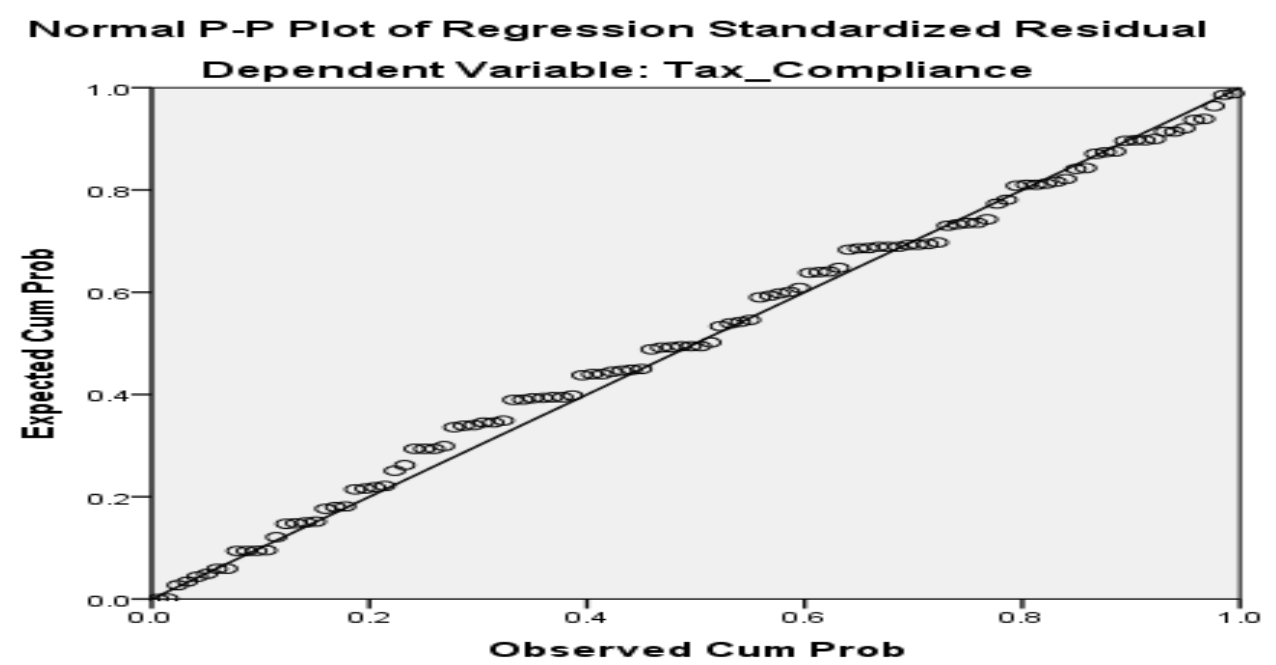

Gambar 1.

Grafik Normal P-P Plot

Sebelum melakukan pengujian hipotesis dengan regresi berganda, tentunya model harus memenuhi asumsi klasik yang disyaratkan dalam pengujian statistik seperti uji normalitas, multikolinearitas, heteroskedastisitas dan uji autokorelasi. Menurut Imam Ghozali (2011), suatu model regresi dapat dikatakan berdistribusi normal apabila titik-titik (plot) yang menggambarkan kondisi data sebenarnya telah mengikuti garis diagonal dalam grafik Normal P-P Plot of Regression Standardized Residual. Pada gambar 1, dapat dilihat bahwa titik-titik data sebenarnya berada disekitar garis diagonal atau mengikuti garis diagonal grafik. Sehingga dapat dikatakan bahwa data dalam model regresi penelitian ini sudah berdistribusi normal.

Imam Ghozali (2011) menyatakan bahwa tidak akan terjadi gejala multikolinearitas yang sering terjadi pada model regresi berganda, apabila nilai Tolerance lebih besar dari 0,10 dan nilai VIF lebih kecil dari 0,10. Berdasarkan tabel 3 dapat dilihat bahwa baik nilai Tolerance maupun nilai VIF sudah memenuhi kriteria yang baik, sehingga dapat dikatakan bahwa model terbebas dari gejala multikolinearitas. Selain itu, untuk menguji model yang digunakan terbebas dari gejala heteroskedastisitas dapat digunakan gambar scatterplot. Imam Ghozali (2011) menyatakan bahwa tidak terjadi heteroskedastisitas apabila tidak ada pola yang jelas (bergelombang, melebar, dan menyempit) pada gambar scatterplot, serta titik-titik menyebar dibawah dan diatas angka 0 pada sumbu Y. Berdasarkan gambar 2, dapat dilihat bahwa titik-titik dalam scatterplot tidak menunjukkan pola dan berada diatas angka 0 pada sumbu Y, sehingga dapat dikatakan bahwa model terbebas dari gejala heteroskedastisitas.

Selanjutnya, dalam pengujian autokorelasi tentunya perlu memastikan nilai Durbin Watson berada diantara nilai (du) sampai dengan (4-du) yang menunjukkan syarat terbebasnya suatu model dari gejala autokorelasi (Imam Ghozali, 2011). Nilai (du) dapat diperoleh dengan menggunakan tabel durbin watson yang mengacu pada indikator jumlah variabel terikat $(\mathrm{K}=2)$ dan jumlah sampel $(\mathrm{N}=110)$ dengan taraf signifikansi 5\%, sehingga nilai (du) diperoleh sebesar 1,73. Apabila digambarkan dalam kriteria yang dimaksud di atas, nilai du (1,73) < Durbin-Watson $(2,00)<4$-du $(2,27)$, artinya nilai durbin watson sudah berada diantara nilai yang disyaratkan. Sehingga dapat dikatakan bahwa tidak terdapat gejala autokorelasi pada model. 


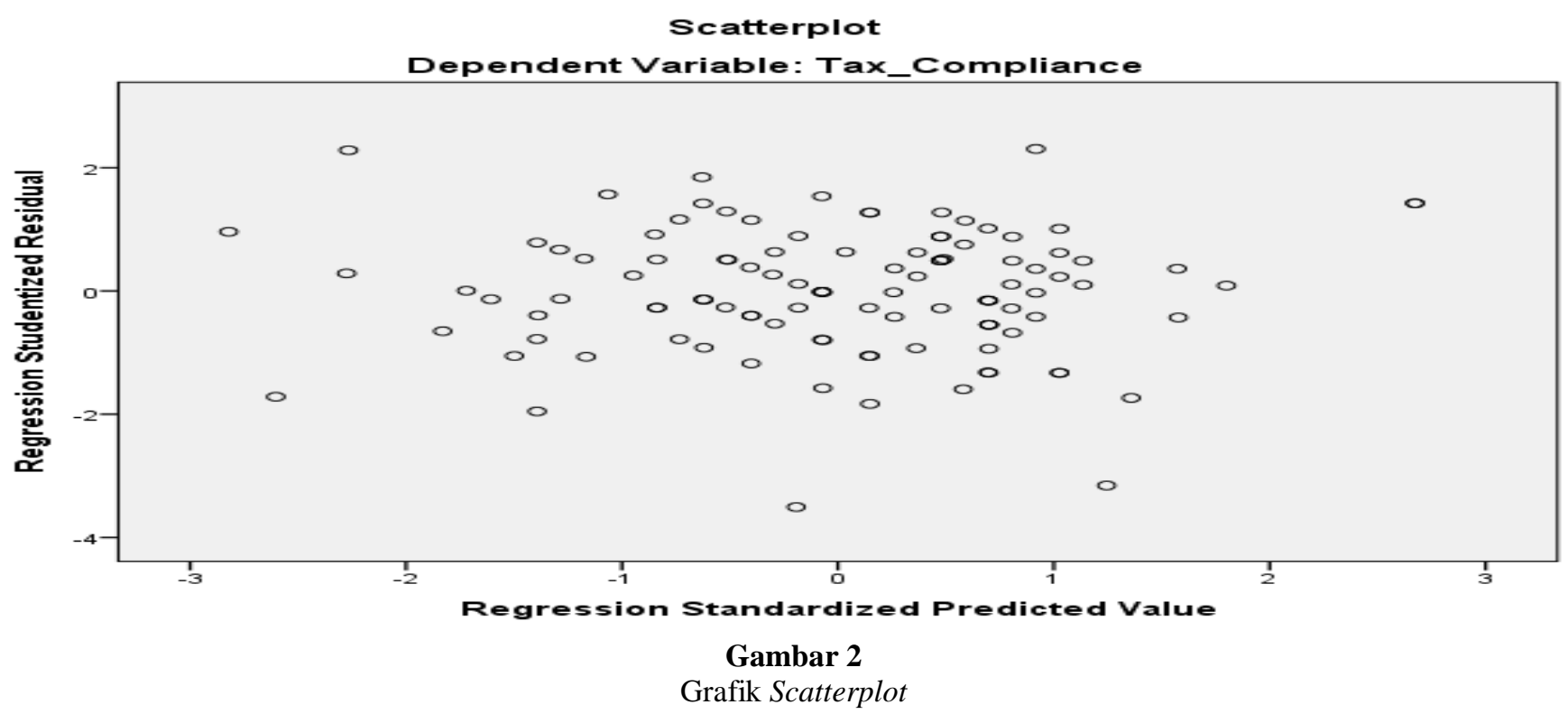

Dalam pengujian hipotesis terkait pengaruh dari masing-masing variabel independen terhadap variabel dependen digunakan uji-t parsial (pengaruh sendiri-sendiri) dan uji-F simultan (pengaruh bersama-sama). Imam Ghozali (2011) menyatakan bahwa apabila nilai signifikansi <0,05 maka dapat dikatakan bahwa nilai variabel independen berpengaruh terhadap variabel dependen. Berdasarkan tabel 3, menunjukkan bahwa pada hipotesis pertama mengenai pengaruh positif variabel Tax Administration (x_1) terhadap variabel Tax Compliance (y) memiliki nilai signifikansi lebih kecil dari 0,05 dengan koefisien arah positif sebesar 5,17 sehingga dapat disimpulkan bahwa hipotesis 1 terbukti sesuai dengan prediksi. Hipotesis 2, terkait pengaruh positif variabel Tax Policy (x_2) terhadap variabel Tax Compliance (y) dapat dilihat pada tabel 3 yang menunjukkan bahwa nilai signifikansi $<0,05$ dengan nilai koefisien positif sebesar 2,90 sehingga dapat disimpulkan bahwa hipotesis 2 juga terbukti sesuai dengan prediksi. Artinya, semakin tinggi persepsi wajib pajak terhadap kebijakan perpajakan, maka semakin tinggi pula tingkat kepatuhan pajak. Berdasarkan pengujian hipotesis secara parsial menunjukkan bahwa masing-masing dari variabel independen dalam penelitian ini yaitu variabel Tax Administration (Administrasi Pajak) dan Tax Policy (Kebijakan Pajak) secara sendiri-sendiri mempunyai pengaruh positif terhadap variabel dependennya yaitu Tax Compliance (Kepatuhan Pajak).

Tabel 3

Uji Hipotesis $\mathrm{H}_{1}$ dan $\mathrm{H}_{2}$

\begin{tabular}{|c|c|c|}
\hline Variabel Independen & Prediksi Arah & $\begin{array}{l}\text { Variabel Dependen } \\
\text { Tax Compliance }\end{array}$ \\
\hline Intercept & & $\begin{array}{c}5,84 * * * \\
(1,35)\end{array}$ \\
\hline Tax Administration & + & $\begin{array}{c}5,17 * * * \\
(0,06)\end{array}$ \\
\hline Tax Policy & + & $\begin{array}{c}2,90 * * * \\
(0,29)\end{array}$ \\
\hline R-squared & & 0,59 \\
\hline Tolerance & & 0,38 \\
\hline VIF & & 2,60 \\
\hline Prob (F-Stat) & & 0.00 \\
\hline Durbin-Watson Stat & & 2,00 \\
\hline \# Jumlah Observasi & & 110 \\
\hline \multicolumn{3}{|c|}{$\begin{array}{l}\text { Jumlah observasi dalam penelitian ini sebanyak } 110 \text { responden yang merupakan subjek pajak dalam negeri yang terdiri dari } \\
\text { berbagai latar belakang seperti pekerja tetap maupun tidak tetap, serta pelaku usaha di Indonesia. Data yang digunakan berasal } \\
\text { dari pengumpulan kuesioner yang dilakukan baik secara elektronik maupun secara langsung. Nilai setiap variabel diukur } \\
\text { berdasarkan } 5 \text { skala likert yang terdiri dari jawaban "Sangat Tidak Setuju (STS)" hingga "Sangat Setuju (SS)". Tanda ***, } \\
* * \text {, dan * mengindikasikan signifikansi level } 0.01,0.05 \text {, dan } 0.10 \text { (one-tailed). }\end{array}$} \\
\hline
\end{tabular}


Pada Tabel 3 dapat dilihat bahwa nilai prob (F-stat) yang diperoleh dari tabel ANOVA sebesar 0,00 lebih kecil dari 0,05, yang menunjukkan bahwa kedua variabel independen dalam penelitian ini mempunyai pengaruh secara simultan (bersama-sama) terhadap variabel dependen dengan nilai R-Squared sebesar 0,59.

\section{HASIL DAN PEMBAHASAN}

\section{Pengaruh Administrasi Pajak terhadap Kepatuhan Pajak}

Pengujian hipotesis yang telah dilakukan terbukti bahwa terdapat pengaruh positif antara administrasi perpajakan dengan kepatuhan pajak. Hal ini mendukung temuan penelitian Antonides dan Robben (1995) dan Webley (2004) yang menyatakan bahwa persepsi mendasar wajib pajak yang berkaitan dengan administrasi perpajakan yang digambarkan melalui transparansi sistem perpajakan, akuntabilitas dan kepercayaan wajib pajak terhadap pemerintah, serta efektivitas pengelolaan pajak oleh pemerintah tentunya akan dapat meningkatkan kepatuhan pajak di suatu negara. Administrasi pajak yang baik tidak cukup hanya dilihat dari kemampuannya dalam mengumpulkan penerimaan pajak, namun juga perlu dilihat dari hubungan kerjasama yang terjalin antara pemangku kepentingan dengan wajib pajak. Dalam beberapa tahun ini pemerintah sepertinya sedang fokus dalam menjalankan reformasi perpajakan agar tercipta lingkungan yang lebih kondusif antara pemerintah dan wajib pajak. Pembenahan administrasi pajak memang tidak dapat dilepaskan dari reformasi pajak, apabila reformasi pajak dapat berjalan dengan baik tentunya dapat menciptakan kepatuhan pajak yang tinggi di Indonesia.

Reformasi pajak yang dilakukan tentunya diharapkan dapat memnbangun kondisi dimana institusi pajak menjadi semakin kuat, kredibel, dan akuntabel yang mempunyai proses bisnis yang efektif dan efisien. Reformasi di area administrasi pajak tentunya memegang peranan penting, perubahan administrasi pajak harus disusun dengan mempertimbangkan situasi pajak dan ekonomi baik di dalam negeri maupun diluar negeri. Selain itu, administrasi pajak harus mampu menggambarkan era transparansi di sekor pajak yang diwujudkan dalam keterbukaan baik dari sisi wajib pajak maupun otoritas pajak. Kemudian hak-hak dari wajib pajak harus semakin dihormati dalam interaksi antara otoritas dan wajib pajak sehingga dimasa depan diharapkan dapat mewujudkan suatu paradigma baru yang disebut dengan "cooperative compliance".

Robbert Veldhuizen (2015) menyebutkan bahwa yang dimaksud dengan cooperative compliance merupakan bentuk paradigma yang mensyaratkan adanya hubungan yang terjalin atas dasar transparansi, keterbukaan, saling percaya dan saling memahami antar wajib pajak, otoritas pajak, dan konsultan pajak. Dengan kata lain, isu pajak yang dapat menjadi persoalan sengketa yang terjadi selama ini dapat dicegah dan didiskusikan sejak awal sehingga menciptakan keterbukaan informasi dan kesetaraan dalam pemenuhan hak dan kewajiban perpajakan yang membuat wajib pajak merasa dilayani dengan baik dan pada akhirnya akan berdampak besar terhadap peningkatan kepatuhan pajak di Indonesia.

\section{Pengaruh Kebijakan Pajak terhadap Kepatuhan Pajak}

Semakin tinggi persepsi mendasar wajib pajak terhadap kebijakan pajak yang diterapkan oleh pemerintah, maka semakin tinggi pula tingkat kepatuhan wajib pajak. Hal ini terbukti pada hipotesis 2 yang menunjukkan adanya pengaruh positif antara kebijakan pajak dengan kepatuhan pajak, hasil penelitian ini mendukung temuan Simons dan Cheng (1996) yang telah melakukan identifikasi terhadap faktor yang dapat mempengaruhi kepatuhan pajak dan menemukan bahwa tingkat kepatuhan wajib pajak memang sangat bergantung dengan kebijakan yang ditetapkan oleh pemerintah dalam mengatur perpajakan di suatu negara. Suatu kebijakan yang baik tentunya harus dirancang dengan mempertimbangkan kapasitas administrasi yang menjalankan kebijakan tersebut. Administrasi pajak yang labil dan korup haruslah dihindari karena dapat menciptakan turunnya kepercayaan terhadap pemerintah yang akhirnya justru melemahkan kepatuhan pajak yang sudah dibangun selama ini. Secara normatif, kebijakan pajak tentunya harus menuju "first best policy" yang mengedepankan faktor-faktor efisiensi, netralitas dan sebagainya (Darussalam et.al, 2019).

Brooks dan Hwong (2006) menyatakan bahwa pajak dapat menimbulkan harga yang harus dibayar yaitu biaya ekonomi. Akan tetapi, perlu diingat bahwa pemungutan pajak dilakukan demi tujuan manfaat yang lebih besar, tidak hanya sebatas masalah ekonomi namun lebih ke sisi moralitas. Oleh sebab itu, setiap kebijakan pajak harusnya dirancang sedemikian rupa sehingga dapat mencapai tujuan yang lebih besar yaitu mengarahkan masyarakat pada kesejahteraan dan keadilan sosial. Kebijakan pajak sebagai wujud reformasi sistem perpajakan tentunya harus mampu beradaptasi dengan setiap pihak yang terlibat didalamnya. Selain 
itu, kebijakan-kebijakan yang dibangun juga perlu memperhatikan kebijakan di negara lain. Dengan adanya hubungan kerjasama antara Indonesia dengan negara lain tentunya dapat berdampak secara langsung maupun tidak langsung terhadap kondisi ekonomi dan situasi pajak di negara lain. Melalui pajak tentunya dapat menggerakkan mobilitas sumberdaya baik modal maupun tenaga kerja, dan pilihan investasi tentunya.Selain itu, pemerintah juga perlu merumuskan strategi dalam meningkatkan kepatuhan pajak dengan fokus terhadap penegakan hukum yang adil dan tegas, melakukan pemeriksaan yang terukur dan sistematis, memberi pelayanan dan sosialisasi mengenai kebijakan kepada masyarakat dan mempermudah segala urusan administrasi di kantor pajak. Semakin baik pemerintah dalam memperlakukan wajib pajak, semakin tinggi pula motivasi wajib pajak untuk patuh. Dengan demikian, diharapkan dapat terwujudnya suatu kebijakan yang mampu mendongkrak tingkat kepatuhan pajak di Indonesia.

\section{SIMPULAN}

Penelitian ini bertujuan untuk memberikan bukti empiris mengenai pengaruh dari persepsi mendasar wajib pajak terhadap tingkat kepatuhan pajak di Indonesia. Penelitian ini berusaha mengeksplorasi faktorfaktor yang dapat meningkatkan kepatuhan pajak dengan melihat dari 2 perspektif mendasar seperti administrasi perpajakan dan kebijakan pajak yang diterapkan oleh pemerintah. Hasilnya terbukti bahwa persepsi mendasar terkait administrasi dan kebijakan perpajakan mampu untuk meningkatkan kepatuhan masyarakat dalam menuntaskan hak dan kewajiban perpajakannya. Administrasi pajak yang baik tidak cukup hanya dilihat dari kemampuannya dalam mengumpulkan penerimaan pajak, namun juga perlu dilihat dari hubungan kerjasama yang terjalin antara pemangku kepentingan dengan wajib pajak. Sedangkan Kebijakan pajak sebagai wujud reformasi sistem perpajakan tentunya harus mampu beradaptasi dengan setiap pihak yang terlibat didalamnya. Kebijakan pajak harus fokus terhadap penegakan hukum yang adil dan tegas, melakukan pemeriksaan yang terukur dan sistematis, memberi pelayanan dan sosialisasi mengenai kebijakan kepada masyarakat dan mempermudah segala urusan administrasi di kantor pajak. Sehingga Semakin baik pemerintah dalam memperlakukan wajib pajak, semakin tinggi pula motivasi wajib pajak untuk patuh.

Dalam penelitian ini terdapat beberapa keterbatasan. Pertama, penelitian ini hanya mengukur nilai kepatuhan pajak berdasarkan 2 persepsi mendasar yang hanya dilihat dari segi administrasi dan kebijakan pajak. Mungkin masih ada faktor lain yang dapat mempengaruhi tingkat kepatuhan wajib pajak yang belum dimasukkan dalam penelitian ini. Oleh karena itu, saran untuk penelitian selanjutnya agar dapat memperdalam mengenai kepatuhan pajak dengan memperkaya variabel dependen yang dapat mempengaruhi tingkat kepatuhan pajak.

\section{DAFTAR PUSTAKA}

Antonides, G. and Robben, H.S.J. (1995), "True positives and false alarms in the detection of tax evasion", Journal of Economic Psychology, Vol. 16 No. 4, pp. 617-640. Armah

Bagchi, Amaresh, Richard Bird, and Arindam das-Gupta (1995). "An Economic Approach to Tax Administration Reform," International Centre for Tax Studies, University of Toronto, Toronto, CA

Bird, Richard, M. Improving Tax Administration in Developing Countries. Journal of Tax Administration Vol. 1. No.1.

Coady, D., de Mooij, R., \& B, Shang. (2015). Inequality and Fiscal Redistribution in Advanced Economies. Inequality and Fiscal Policy, 37-56.

Darussalam, Danny, S., B.Bawono, K., \& Denny, V. (2019). Era Baru Hubungan Otoritas Pajak dengan Wajib Pajak. Dimensi Internasional Tax: Jakarta.

Frey, B. and Torgler, B. (2007), "Tax morale and conditional cooperation", Journal of Comparative Economics, Vol. 35, pp. 136-159.

Jonathan Sarwono. (2006). Metode Penelitian Kuantitatif dan Kualitatif. Graha Ilmu:Yogyakarta.

Imam Ghozali. (2011). Aplikasi Analisis Multivariate dengan Program IBM. SPSS.

Inside Tax (2018). Berebut Suara Wajib Pajak. Edisi Khusus. Desember 2018. Media Tren Perpajakan.

James, S. and Alley, C. (2004) Tax Compliance, Self Assessment and Tax Administration. Journal of Financial and Management in Public Services, 2, 27-42. 
Neil Brooks dan Thaddeus Hwong. (2006). The Social Benefits and Economic Cost of Taxation. Canadian Centre for Policy Alternatives. Vol X: 1-2.

Ritsatos, T. (2014), Tax evasion and compliance; from the neo classical paradigm to behavioural economics, a review. Journal of Accounting \& Organizational Change, Vol. 10 No. 2 pp. 244-262

Robert Veldhuizen (2015). Cooperative Compliance: Large Business and Compliance, dalam Tax Assurance, ed. Ronald Russo (The Hague: Kluwer Law, 2015), 135-138.

Sanya, S., and Mulondo, L. (2015), City Paralysed as traders, URA clash. URA vowed to continue with its tough stance on traders, calling the strike sabotage, New Vision 4 December p.1\&3.

Simmons, R.S and Cheng, T.Y. (1996), "Citizens' Attitudes Towards Tax Evasion in Hong Kong”, Asian Journal of Accounting, Vol. 4 No. 1 pp 98 - 117.

Torgleer, Benno., \& M.Schaffner. 2008. Causes and consequences of Tax Morale: An Empirical Investigation. Economic Analysis and Policy Vol. 38, No.2.

Webley, P. (2004), in "Tax compliance by businesses", Sjo“gren, H. and Skogh, G. (Eds), New Perspectives on Economic Crime, Edward Elgar, Cheltenham. 